\title{
KEPEMIMPINAN PENDIDIKAN
}

\author{
Nofita Sari \\ E-mail \\ nofitasari91199@gmail.com \\ Universitas Negeri Padang
}

\begin{abstract}
Abstrak
Kepemimpinan pendidikan merupakan kemampuan untuk mempengaruhi, mengkoordinir, dan menggerakkan orang-orang lain yang ada hubungannya dengan pelaksanaan dan pengembangan pendidikan agar dapat dicapai tujuan pendidikan ata sekolah secara efektif dan efisien. Agar tujuan sekolah dapat dicapai secara efektif dan efisien dibutuhkan kepemimpinan kepala sekolah yang efektif. Maka dari itu kepepimpinan sangat dibutuhkan dalam dunia pendidikan apalagi kepemimpinan yang berkualitas dan mampu menjadi pemimpinan yang dapat menjalankan pendidikan dengan baik.
\end{abstract}

Kata kunci:Kepemimpinan, Pendidikan

\section{A. PENDAHULUAN}

Mencerdaskan kehidupan bangsa merupakan tujuan ideal untuk direalisasikan melalui sistem pendidikan nasional. Dalam sistem sekolah, terjadi proses interaksi antara kepala sekolah, guru, pegawai, pengawas, komite sekolah serta murid. Semua proses interaksi berlangsung, karena dipengaruhi fungsi pengorganisasian, pembagian tugas, komunikasi, motivasi, kewenangan dan keteladanan. Kepala sekolah berfungsi sebagai pemimpin, manajer, pendidik, pengawas, dan motivator bagi guru-guru dalam proses kependidikan melalui pembelajaran dan latihan.
Guru berinteraksi dengan sesama guru dan murid dalam kegiatan pembelajaran. Pada era informasi saat ini, keberhasilan dan kegagalan suatu organisasi sekolah sebagian besar ditentukan oleh mutu kepemimpinan yang dimiliki oleh orang-orang yang diserahi tanggungjawab sebagai pemimpin dalam suatu organisasi sekolah. Untuk itu kepemimpinan pendidikan perlu diberdayakan dengan cara meningkatkan kemampuannya secara fungsional, sehingga mampu berperan sesuai dengan tugas, wewenang, dan tujuannya. 


\section{B. PENGERTIAN KEPEMIMPINAN PENDIDIKAN}

Kepemimpinan pendidikan merupakan kemampuan untuk menggerakkan pelaksanaan pendidikan, sehingga tujuan pendidikan yang telah ditetapkan dapat dicapai secara efektif dan efisien (Makawimbang, 2012: 29). Soetopo dan Soemanto menjelaskan bahwa kepemimpinan pendidikan adalah kemampuan untuk mempengaruhi dan menggerakkan orang lain untuk mencapai tujuan pendidikan secara bebas dan sukarela.

Secara sederhana kepemimpinan merupakan kemampuan yang dimiliki seseorang untuk mempengaruhi orang lain (Makawimbang, 2012: 6). Hal ini berarti kepemimpinan merupakan suatu kemampuan seseorang untuk mempengaruhi orang lain agar mengikuti keinginan seorang pemimpin. Kepemimpinan adalah kemampuan mempengaruhi perilaku orang lain dalam situasi tertentu agar bersedia bekerjasama untuk mencapai tujuan yang ditetapkan.

Menurut Syafaruddin (2010: 47), pemimpin dipercaya oleh yang dipimpin karena otoritas dan kemampuannya untuk memberikan pengaruh kepada anggota untuk melakukan sesuatu. Orang yang menjalankan proses kepemimpinan disebut pemimpin. Sedangkan orang yang dipimpin disebut anggota atau pengikut (folowwers). Dalam berbagai tindakannya seorang pemimpin mempengaruhi anggota, karena itu, peran para pemimpin sangat signifikan dalam menentukan arah dan kualitas kehidupan manusia, baik dalam keluarga, masyarakat, bangsa, serta negara.

Menurut hasil penelitian ada beberapa cara untuk menjadi pemimpin yang efektif yaitu:

a. Latihan mengenali diri anda dan menyadari kekuatan dan kelemahan anda. Untuk mengatasi kegagalan dengan memanfaatkan peluang latihan. Latihan dalam bidang berbicara di depan masyarakat, pengambilan keputusan, pemecahan masalah, peningkatan jaminan pribadi dan visi yang kuat;

b. Gaya mengenali dan mengontrol gaya kepemimpinan anda. Kebanyakan pemimpin cenderung berorientasi ke arah tugas atau orientasi manusia. Tetapi gaya yang sangat tepat adalah bergantung atas kombinasi dari situasi, tugas, dan melibatkan manusia. Pemeliharaan sikap fleksibilitas yang membolehkan anda untuk memiliki 
gaya yang tepat terhadap situasi di mana anda memimpin;

c. Mengenali dan memberi dukungan kepada bawahan. Para bawahan ingin diperlakukan sebagai individu yang mampu. Ciptakan atmosphir yang mendukung bawahan mencapai tujuan kerja mereka dan kebutuhan pribadi mereka;

d. Sifat dasar pekerjaan perlu diadaptasi. Bagi yang kreativitasnya tinggi dan tugas kewirausahaan, sifat dasar pekerjaan mungkin saja tertarik untuk menyusun tujuan yang luas bagi bawahan anda dan kemudian membiarkannya atas usaha/penilaian mereka untuk bekerja mencapai tujuan tersebut

\section{KEPEMIMPINAN}

KEPALA

\section{SEKOLAH}

Ada beberapa prinsip kerja sekolah sebagai organisasi, menurut Roe dan Drake (1980: 76), yaitu:

a. Sekolah tidak dapat mencapai efektivitas dengan pembatasan pemahaman atas fungsinya. Rendahnya tingkat kepercyaan dan pengertian masyarakat akan membatasi efektivitas sekolah;

b. Pentingnya tuntutan pendidikan yang membuatnya dilindungi dan sanggahan oleh berbagai pihak partisan politik; c. Proses pendidikan yang rumit hanya akan dapat dilaksanakan melalui sejumlah lembaga, perwakilan dan aktivitas kerjasama, koordinasi dan keterpaduan pendiidikan dan lembaga sosial adalah aktivitas penting dari suatu sekolah;

d. Organisasi yang efektif akan menekankan dan menggunakan secara tetap dalam keseimbangan yang lebih baik dan elemen anggota dan aktivitas administratif, yaitu:

1) Perencanaan;

2) Pengorganisasian;

3) Penempatan staf;

4) Kepemimpinan;

5) Komunikasi/interpretasi;

Dalam menjalankan organisasi sekolah dibutuhkan kepemimpinan kepala sekolah. Kepemimpinan kepala sekolah dapat diartikan sebagai proses membina hubungan timbal balik antara pemimpin dengan yang dipimpin dengan mengandalkan kemampuan komunikasi interpersonal sehingga terjalin saling pengertian dan kerjasama antar personil (sesuai tanggung jawab dan tugas yang ditetapkan di sekolah). Kepemimpinan kepala sekolah adalah cara atau usaha kepala sekolah dalam mempengaruhi, mendorong, membimbing, mengarahkan dan menggerakkan guru, staf, siswa, orang tua siswa dan pihak 
lain yang terkait untuk bekerja atau berperanserta guna mencapai tujuan yang telah ditetapkan (Diknas, 1999).

\section{DAFTAR PUSTAKA}

Makawimbang, Jery H., Kepemimpinan Pendidikan yang Bermutu (Bandung: Alfa Beta,

Roe, W.H. T dan Drake, The Principalship, (New York: Macmilalan Publishing, 1980).

Soetopo, Hendyat dan Soemanto, Pengantar Operasional administrasi Pendidikan,

(Surabaya: Usaha Nasional, 1982).

Syafaruddin, Kepemimpinan Pendidikan, (Jakarta: Quantum Teaching, 2010). 